\title{
Cytotoxicity and antioxidant activity of goldenberry extracts obtained with high intensity ultrasound
}

\author{
Cristiane Franco Codevilla ${ }^{1^{*}}$ Bruna Tischer $^{1}$ Amanda Leitão Gindri ${ }^{2}$ \\ Daniele Rubert Nogueira-Librelotto ${ }^{2}$ Juliano Smanioto Barin ${ }^{1}$ Cristiane de Bona da Silva ${ }^{2}$ \\ Clarice Madalena Bueno Rolim ${ }^{2}$ Leila Queiroz Zepka ${ }^{1}$ Cristiano Ragagnin de Menezes ${ }^{1}$
}

1'Departamento de Tecnologia e Ciência dos Alimentos, Universidade Federal de Santa Maria (UFSM), 97105-900, Santa Maria, RS, Brasil.
E-mail: cristianefc@ hotmail.com. *Corresponding author.
${ }^{2}$ Departamento de Farmácia Industrial, Universidade Federal de Santa Maria (UFSM), Santa Maria, RS, Brasil.

ABSTRACT: The high intensity ultrasound-assisted extraction (HIU) is one of the most simple, quick and efficient techniques for the extraction of phenolic and other antioxidant compounds from plants. This is the first application of HIU for the extraction of these compounds from goldenberry fruit. The HIU and conventional extraction techniques showed similar results regarding to phenolic compounds and antioxidant capacity. However, the time required for HIU extraction (5min) was 24 times lower than conventional extraction (120min). Phenolic compounds reported were chlorogenic acid, caffeic acid and rutin. In vitro cytotoxicity assays were used for evaluation of extracts and the results showed that in a wide range of concentration, the extract maintains cell viability, thus indicating the possibility to use it as food with safety. Key words: goldenberry; sonication; antioxidant capacity; cytotoxicity; high performance liquid chromatography.

Citotoxicidade e atividade antioxidante de extratos de goldenberry obtidos com ultrassom de alta intensidade

RESUMO: A extração assistida com ultrassom de alta intensidade (HIU) é uma das técnicas mais simples, rápidas e eficientes na extração de compostos fenólicos e antioxidantes de plantas. Este trabalho foi o primeiro a utilizar HIU na extração destes compostos presentes na fruta goldenberry. As técnicas HIU e extração convencional apresentaram resultados semelhantes com relação aos compostos fenólicos e capacidade antioxidante. Entretanto, o tempo necessário na HIU (5min) foi 24 vezes menor que na extração convencional (120min). Os compostos fenólicos encontrados foram ácido clorogênico, ácido cafeico e rutina. Ensaios de citotoxicidade in vitro foram usados para avaliação dos extratos e os resultados demonstraram que, em ampla faixa de concentração, o extrato mantém a viabilidade celular, indicando assim possivel segurança para utilização em alimentos.

Palavras-chave: goldenberry, sonicação, capacidade antioxidante, citotoxicidade, cromatografia líquida de alta eficiência.

\section{INTRODUCTION}

Goldenberry (Physalis peruviana L.) belongs to the family Solanaceae, which have about 120 species, distributed in tropical and subtropical regions of Africa, Asia and America (KUSPKA \& JÉLEN, 2016). The bioactive compounds present in the fruit of goldenberry, especially phenolic compounds, have important pharmacological properties, such as antioxidant, antibacterial, antitumor, antinflammatory and immunosuppressive action (KUSPKA \& JÉLEN, 2016).

The extraction is the first step to obtain bioactive compounds from plant materials, and conventional solvent extractions, such as maceration, percolation, soxhlet and stirring methods, are the most widely used (PATIL \& AKAMANCHI, 2017). However, these methods consume large amounts of solvents with poor extraction efficiency, long times of extraction with low efficiency (SHIRSATH et al., 2012). As an innovative technology, HIU has been proposed in recent years as a tool to improve extraction efficiency and reduce solvent consumption (CHEMAT et al., 2013; KUMARI et al., 2017).

For goldenberry, the extraction of phenolic compounds with ultrasound was performed only by the use of baths (LICODIEDOFF et al., 2013) and no applications of HIU were reported. In addition, the information about the toxicity of extracts of goldenberry is scarce. Thus, in 
the present research, HIU was compared with conventional solvent extraction by using the determination of total phenolic compounds and antioxidant capacity method ORAC (Oxygen Radical Absorbance Capacity). A high performance liquid chromatography (HPLC) method was developed for the chromatographic separation, identification and simultaneous quantitative determination of phenolic compound in each extract. The in vitro cytotoxicity of the obtained extracts using non-tumor cell lines (3T3, murine Swiss albino fibroblasts) and two cytotoxicity assays, 3-(4,5-dimethylthiazol-2-yl)-2,5diphenyltetrazolium bromide (MTT) and neutral red uptake (NRU) assay were also performed.

\section{MATERIALS AND METHODS}

\section{Plant material and reagents}

Goldenberry were purchased from Italbraz (Vacaria, Brazil) located at 28:0:44 $\mathrm{S}$ and 50:56:02 W. Samples were stored at $-18^{\circ} \mathrm{C}$ till analyses. All extract were prepared with peel, pulp and seeds of the ripe fruit. All reagents used were from analytical grade. Gallic acid, Trolox, AAPH, fluorescein, caffeic acid, chlorogenic acid, rutin, phosphate buffered saline (PBS), MTT, NR dye, DMSO and trypsin-EDTA solution were obtained from Sigma-Aldrich (St. Louis, USA). Folin-Ciocalteau reagent and formic acid were obtained from Merck (Darmstadt, Germany), sodium carbonate was purchased from Vetec (Duque de Caxias, Brazil); Fetal bovine serum (FBS) and Dulbecco's Modified Eagle's Medium (DMEM) were purchased from Vitrocell (Campinas, Brazil).

\section{Conventional extraction method}

Extracts were obtained following the method used by ROCKENBACH et al. (2008) with some modifications. Fresh fruit samples $(15 \mathrm{~g})$ were ground and $25 \mathrm{~mL}$ of extraction solvent (methanol or ethanol $60 \%(\mathrm{v} / \mathrm{v}))$ was added with magnetic stirring protected from light for two hours. The extracts were filtered through a $0.45 \mu \mathrm{m}$ polyamide filter (Sartorius Stedim Biotec) and stored until analysis.

\section{High intensity ultrasound-assisted extraction}

For HIU, an ultrasound probe (130W, $20 \mathrm{kHz}$, Sonics and Materials Inc., USA) was used. Samples of fresh fruits $(15 \mathrm{~g})$ were ground and placed in a stainless steel water-cooled reactor, at $4.0^{\circ} \mathrm{C}$. Then, $25 \mathrm{~mL}$ of solvent (methanol or ethanol $60 \%(\mathrm{v} / \mathrm{v})$ ) was added with further sonication by 5 or $15 \mathrm{~min}$ using a power output of $70 \%$. Extracts were filtered through quantitative filter paper and stored until analysis.

\section{Determination of total phenolic compounds}

The determination of total phenolic compounds was performed by spectrophotometric Folin-Ciocalteu method (CHANDRA \& MEJIA, 2004). Gallic acid was used as reference solution for calibration curve from 0.001 to $0.03 \mathrm{mg} / \mathrm{mL}$. Results were expressed as milligrams of gallic acid equivalent per 100 gram of fresh fruit (mg GAE/100g).

\section{HPLC analysis}

Analyses were performed using Luna RP18 column $(250 \times 4.6 \mathrm{~mm}, 5 \mu \mathrm{m}$, Phenomenex, USA) and an Agilent 1260 Infinity (Agilent Technologies, Germany) equipped with G1314B UV detector, G1311C quaternary gradient pump, and G1329B autosampler. The mobile phase consisted of a gradient mixture of solvent A ( $0.45 \%$ formic acid in Milli-Q water) and $\mathrm{B}$ (methanol). The gradient was as follows: $20 \% \mathrm{~B}(5 \mathrm{~min}), 20 \%$ to $52 \% \mathrm{~B}$ (6min), $52 \%$ B (17min), and then returns to initial conditions by $3 \mathrm{~min}$. The flow rate was $0.8 \mathrm{~mL} / \mathrm{min}$, and the injection volume was $20 \mu \mathrm{L}$. Phenolic compounds were monitored at 370nm. Extracts and standard compounds were analyzed under the same analysis conditions.

\section{Antioxidant capacity evaluation}

The ORAC assay was performed as described by OU et al. (2001) by using 96-well microplates (SPL Life Science, Gyeonggi-do, Korea). This kinetic assay is based on the measurement of radical scavenging activity of extract against peroxyl radicals produced by the addition of AAPH radical inductor. Antioxidant capacity was determined using area under curve (AUC) and results were compared to a standard curve of Trolox (from 8 to $96 \mu \mathrm{mol} / \mathrm{L}$ ) and expressed as Trolox equivalents of $\mu \mathrm{mol} / \mathrm{gram}$ of fresh fruit.

\section{Cytotoxicity assays}

The 3T3 cells were seeded into 96-well plate at a density of $1 \times 0^{5}$ cells $/ \mathrm{mL}$. After incubation for $24 \mathrm{~h}$ under $5 \% \mathrm{CO}_{2}$ at $37^{\circ} \mathrm{C}$, the spent medium was replaced with $100 \mu \mathrm{L}$ of fresh medium containing the extract at the concentration range $15.6-2000 \mu \mathrm{g} / \mathrm{mL}$ or with $100 \mu \mathrm{L}$ of medium only for the untreated control cells. After $24 \mathrm{~h}$, the extract-containing medium was removed, and $100 \mu \mathrm{L}$ of MTT $(0.5 \mathrm{mg} / \mathrm{mL})$ or NR $(50 \mu \mathrm{g} / \mathrm{mL})$ solution in FBS-free medium was added for the MTT and NRU assays, respectively. Plates were further incubated for $3 \mathrm{~h}$, after which the medium was removed. Afterward, $100 \mu \mathrm{L}$ of DMSO or of a solution containing 50\% absolute ethanol and $1 \%$ acetic acid in distilled water was then added. Absorbance of solutions was measured at $550 \mathrm{~nm}$ 
using SpectraMax M2 microplate reader (Molecular Devices, CA, USA). Cytotoxicity of the extract was expressed as percentage of viability with regard to untreated control cells (the mean optical density of untreated cells was set at $100 \%$ viability).

\section{Statistical analysis}

Statistical analysis of results were performed using analysis of variance (ANOVA) and Tukey test $(\mathrm{p}<0.05)$. Results were expressed as mean \pm standard deviation of three independent experiments. The cytotoxicity was expressed as percent of viability with regard to untreated control wells, using mean \pm standard deviation of two independent experiments.

\section{RESULTS AND DISCUSSION}

In order to study the best method of extraction, the determination of total phenolic content and antioxidant activity of extracts was determined. In this way, conventional and HIU extractions were performed with two different solvents. As shown in table 1 , no significant difference $(p>0.05)$ was observed for different extraction techniques as well as for different solvents regarding to the amount of total phenolic compounds. Contents of total phenolic compounds reported in this study (around $610 \mathrm{mg}$ $\mathrm{GAE} / 100 \mathrm{~g}$ of fresh fruit) were higher than those found by ROCKENBACH et al. (2008) and LIMA et al. (2012), which were $57.9 \mathrm{mg}$ GAE/ $100 \mathrm{~g}$ of fresh fruit in methanolic extract and $187.59 \mathrm{mg}$ GAE $/ 100 \mathrm{~g}$ of fresh fruit in aqueous extract, respectively. The selection of the most appropriate solvent for extracting the compounds from the matrix is one of the most important operational parameters in the extraction methods (NGO et al., 2017).

Quantitative analysis of the phenolic compounds reported in goldenberry extracts was performed using HPLC. The following phenolic compounds were identified in the extracts: chlorogenic

Table 1 - Content of total phenolic compounds after conventional and high intensity ultrasoundassisted extraction.

\begin{tabular}{lcc}
\hline Method & \multicolumn{2}{c}{ mg GAE/100g of fresh fruit \pm SD } \\
\hline & $60 \%$ Ethanol & $60 \%$ Methanol \\
Conventional extraction & $540 \pm 60$ & $542 \pm 30$ \\
HIU 5min & $612 \pm 87$ & $608 \pm 70$ \\
HIU 15min & $581 \pm 43$ & $598 \pm 16$ \\
\hline
\end{tabular}

acid, caffeic acid and rutin (Table 2), and the retention time were 10.8, 11.5 and 14 minutes (Figure 1), respectively. Chlorogenic acid and rutin have been reported in the goldenberry in other studies (LICODIEDOFF et al., 2013; ROCKENBACH et al., 2008). Together with caffeic acid, these phenolic compounds are responsible for a number of biological activities including antioxidant.

In this way, the antioxidant capacities of these extracts were evaluated. The table 3 presents the results for antioxidant activity of extracts obtained by use of conventional and HIU extraction. Statistical analysis (ANOVA) indicated that the extractions with ethanol and methanol were different. The antioxidant capacity of extract obtained with ethanol was higher. DO et al. (2014) investigated the effects of solvents in the extraction of phenols and antioxidant capacity from Limnophila. They observed that the extraction with ethanol and acetone showed no significant difference in the content of phenolic compounds. However, the antioxidant capacity, measured by different methods, showed that the extracts obtained using ethanol presented statistically higher values than acetona. The authors concluded that the different solvents used in extraction resulted in differences in compositions and antioxidant capacities of the extracts. PANIWNYK et al. (2009) evaluated the effect of different solvents in the extraction of antioxidant compounds from rosemary (rosmarinic acid and carnosic acid), using ultrasonic and conventional extraction. The authors observed that methanol was a more effective solvent for the extraction of total antioxidants than ethanol. However, the analysis of the extracted antioxidant compounds showed that methanol was a better solvent for rosmarinic acid, while ethanol was a better solvent for carnosic acid. Therefore, depending on the solvent used for extraction, different amounts of antioxidant compounds can be extracted.

In the literature, there are different methods for evaluation of the antioxidant capacity of goldenberry, including the trolox equivalent antioxidant capacity (TEAC), 2,2'-diphenylpicryl hydrazyl free radical (DPPH), thiobarbituric acid reactive substances (TBARS), 2,2'-azobis (2-amidinopropane) dihydrochloride (ABTS), ORAC, among others (KUSPKA \& JÉLEN, 2016; LICODIEDOFF et al., 2013; ROCKENBACH et al., 2008). The ORAC is the most widely recognized of all of these antioxidant assays. The method uses the peroxyl radical as pro-oxidant, which is the best model of antioxidant reaction with reactive oxygen species in foods and in vivo (NGO et al., 2017). Moreover, the reactive species interact with the 
Table 2 - Phenolic compounds in goldenberry extracts.

\begin{tabular}{|c|c|c|c|c|}
\hline Method & Solvent & Chlorogenicacid $\mathrm{T}_{\mathrm{R}}{ }^{*}(\mathrm{~min}) 10.8$ & Caffeic acid $\mathrm{T}_{\mathrm{R}}{ }^{*}(\min ) 11.5$ & Rutin $\mathrm{T}_{\mathrm{R}}^{*}(\mathrm{~min}) 14.0$ \\
\hline Conventional extraction & \multirow[t]{3}{*}{ Ethanol $60 \%$} & $42.3 \pm 3.7$ & $9.8 \pm 1.3$ & $4.1 \pm 0.2$ \\
\hline HIU $5 \mathrm{~min}$ & & $22.6 \pm 3,6$ & $6.7 \pm 1.8$ & $5.1 \pm 0.4$ \\
\hline HIU $15 \mathrm{~min}$ & & $20.0 \pm 2.4$ & $5.8 \pm 1.6$ & $5.1 \pm 1.8$ \\
\hline Conventional extraction & \multirow[t]{3}{*}{ Methanol $60 \%$} & $36.3 \pm 1.4$ & $7.3 \pm 2.9$ & $4.5 \pm 0.8$ \\
\hline HIU 5 min & & $18.5 \pm 2.1$ & $5.7 \pm 1.5$ & $4.2 \pm 0.1$ \\
\hline HIU $15 \mathrm{~min}$ & & $27.7 \pm 8.0$ & $5.9 \pm 1.5$ & $4.1 \pm 0.3$ \\
\hline
\end{tabular}

$\mathrm{T}_{\mathrm{R}}^{*}$ : Retention time

substrate until the end of assay and the area under the curve is used for quantitation, while the other methods use a percentage of inhibition at a fixed time (SEPTEMBRE-MALATERRE et al., 2016).

Results of determination of total phenolic compounds and antioxidant capacity did not demonstrate significant difference among the different extraction techniques. However, the time of extraction for conventional method was $120 \mathrm{~min}$, while HIU was only $5 \mathrm{~min}$, which is an important advantage. The time required for extraction will typically depend on the type of material, the cell wall structure, mass transfer resistance for the diffusion of the solvent into the material and the penetration rate of the solvent to plant material (SHIRSATH et al., 2012).

Therefore, the best extraction method was HIU using ethanol as extraction solvent. It is important to mention that ethanol is less toxic than methanol, being generally recognized as a safe solvent being more suitable for further application of



Ciência Rural, v.48, n.2, 2018. 
Table 3 - Antioxidant capacity of goldenberry extracts by different extraction methods using different solvents.

\begin{tabular}{|c|c|c|}
\hline \multirow[t]{2}{*}{ Method } & \multicolumn{2}{|c|}{$\begin{array}{c}\mu \mathrm{mol} \text { trolox equivalent } / \mathrm{g} \text { of fresh } \\
\text { fruit } \pm \mathrm{SD}\end{array}$} \\
\hline & $60 \%$ Ethanol & $60 \%$ Methanol \\
\hline Conventional extraction & $1067 \pm 256^{\mathrm{a}}$ & $456 \pm 131^{b}$ \\
\hline HIU $5 \mathrm{~min}$ & $1251 \pm 127^{\mathrm{a}}$ & $354^{b} \pm 25^{b}$ \\
\hline HIU $15 \mathrm{~min}$ & $1212 \pm 82^{\mathrm{a}}$ & $337^{\mathrm{b}} \pm 46^{\mathrm{b}}$ \\
\hline
\end{tabular}

Mean \pm standard deviation followed by the same letters in the same column, indicate statistically similar at the 0.05 level.

goldenberry extract in food (KUMARI et al., 2017). In order to evaluate the cytotoxicity potential of the ethanol extract of goldenberry two in vitro bioassays, MTT and NRU, were compared.

Cytotoxicity evaluated with non-tumor cell line is an important tool for the prediction of risk and safety assessment of the potential toxicity of bioactive compounds. In vitro systems are mainly used for screening purposes and for generating more comprehensive toxicological profiles (EISENBRAND et al., 2002). It was observed in the NRU assay that a 24h-exposure of cell line to different concentrations of ethanolic extract caused no reduction in the number of viable cells, whereas in the MTT assay there was a slight reduction in cell viability at the concentration of $2000 \mathrm{mg} / \mathrm{mL}$ (Figure 2). Apparently this reduction did not represent cytotoxicity, since the values were above $75 \%$ (ISO 10993-5) (WANG et al., 2015).

\section{CONCLUSION}

This was the first study using high intensity ultrasound-assisted extraction focused on the phenolic and antioxidant compounds from fruits of goldenberry. In comparison with conventional extraction, HIU reduced the time of extraction 24 times with the same efficiency. Ethanol was a better extraction solvent than methanol. Examination of the extracts revealed the presence of phenolic compounds important for human health, like chlorogenic and caffeic acid, and rutin. This research also conducted two in vitro cytotoxicity assays, MTT and NRU, and it was observed that over a wide range of concentration, ethanolic extract of goldenberry did not show in vitro cytotoxicity, demonstrating the possibility of use in food.

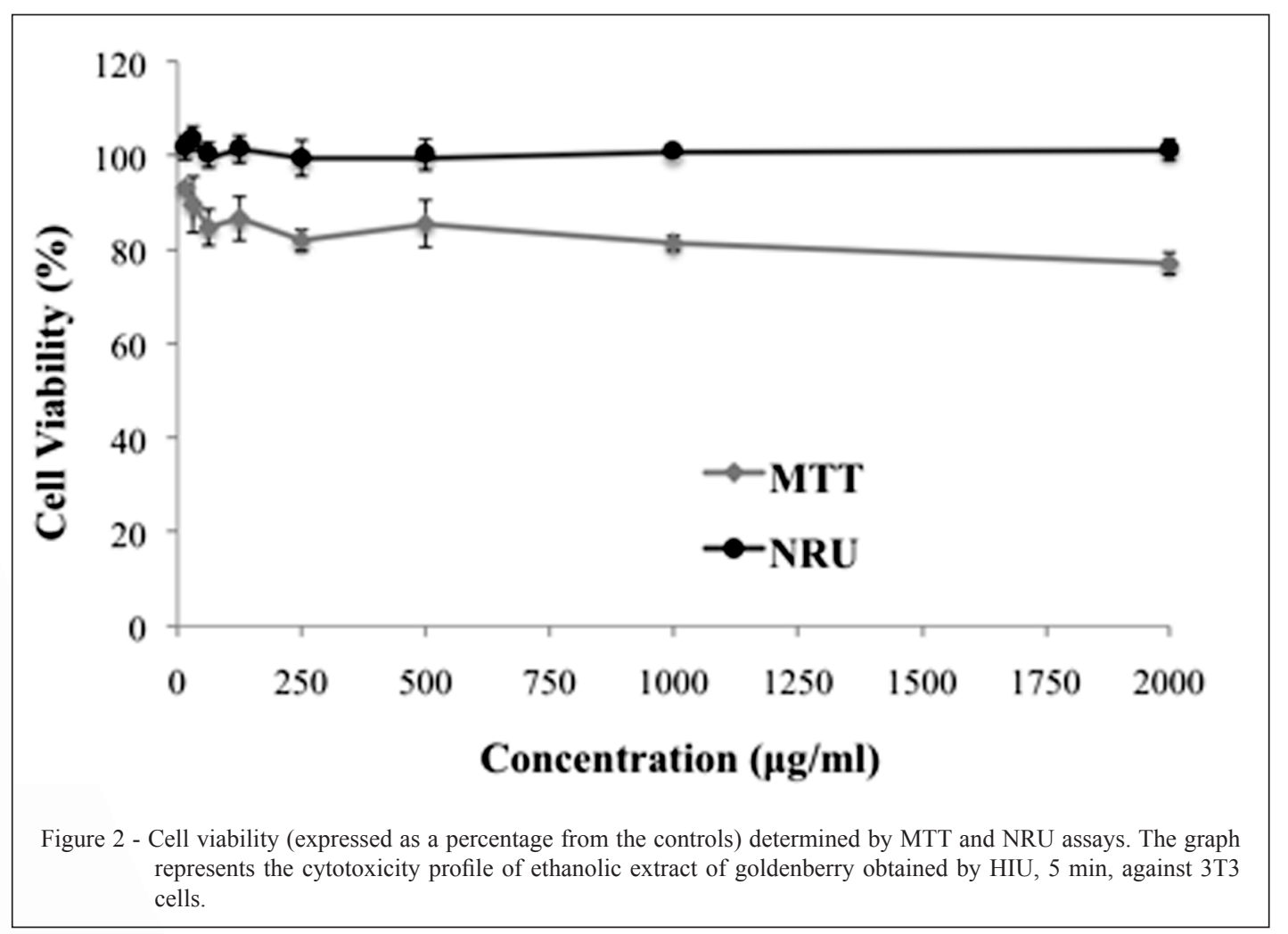

Ciência Rural, v.48, n.2, 2018. 


\section{ACKNOWLEDGEMENTS}

The authors wish to thank the Coordenação de Aperfeiçoamento de Pessoal de Nível Superior (CAPES) for the financial support.

\section{REFERENCES}

CHANDRA, S.; MEJIA, E.G. Polyphenolic compounds, antioxidant capacity, and quinone reductase activity of an aqueous extract of Ardisia compressa in comparison to mate (Ilex paraguariensis) and green (Camellia sinensis) Teas. Journal of Agricultural and Food Chemistry, v.52, n.11, p.3583-3589, 2004. Available from: <http:// pubs.acs.org/doi/abs/10.1021/jf0352632>. Accessed: mar. 23, 2015. doi: $10.1021 / \mathrm{jf0} 352632$.

CHEMAT, F. et al. Applications of ultrasound in food technology: Processing, preservation and extraction. Ultrasonics Sonochemistry, v.18, p.813-835, 2011. Available from: <http://www.sciencedirect. com/science/article/pii/S1350417710002385?via\%3Dihub>. Accessed: jun. 30, 2015. doi: 10.1016/j.ultsonch.2010.11.023.

DO, Q.D. et al. Effect of extraction solvent on total phenol content, total flavonoid content, and antioxidant activity of Limnophila aromatica. Journal of Food and Drug Analysis, v.22, p.296-302, 2014. Available from: <https://linkinghub.elsevier.com/retrieve/ pii/S1021-9498(13)00134-8>. Accessed: sep. 26, 2015. doi: 10.1016/j.jfda.2013.11.001

EISENBRAND, G. et al. Methods of in vitro toxicology. Food and Chemical Toxicology, v. 40, p.193-236, 2002. Available from: <http://www.sciencedirect.com/science/ article/pii/S0278691501001181?via\%3Dihub>. Accessed: ago. 20, 2015. doi: 10.1016/S0278-6915(01)00118-1.

KUMARI, B. et al. Ultrasound-assisted extraction of polyphenols from potato peels: profiling and kinetic modelling. International Journal of Food Science \& Technology, v.52, n.6, p.1432-1439, 2017. Available from: <http://onlinelibrary.wiley.com/doi/10.1111/ ijfs.13404/abstract>. Accessed: mar. 9, 2017. doi: 10.1111/ ijfs. 13404.

KUSPKA, M.; JÉLEN, H.H. In-tube extraction for the determination of the main volatile compounds in Physalis peruviana L. Journal of Separation Science, v.40, n.2, p.532-541, 2016. Available from: $<$ http://onlinelibrary.wiley.com/doi/10.1002/jssc.201600797/pdf $>$. Accessed: mar. 12, 2017. doi: 10.1002/jssc.201600797.

LICODIEDOFF, S. et al. Flavonols and antioxidant activity of Physalis peruviana L. fruit at two maturity stages. Acta Scientiarum Technology, v.35, n.2, p.393-399, 2013. Available from: <http://periodicos.uem.br/ojs/index.php/ActaSciTechnol/ article/view/13265/pdf 1>. Accessed: sep. 14, 2013. doi:10.4025/ actascitechnol.v35i2.13265.

LIMA, C.S.M. et al. Avaliação física, química e fitoquímica de frutos de Physalis, ao longo do período de colheita.
Revista Brasileira de Fruticultura, v.34, n.4, p.1004-1012, 2012. Available from: <https://www.embrapa.br/web/mobile/ publicacoes/-/publicacao/955768/avaliacao-fisica-quimica-efitoquimica-de-frutos-de-physalis-ao-longo-do-periodo-decolheita>. Accessed: sep. 13, 2013.

NGO, T.V. et al. Impact of different extraction solvents on bioactive compounds and antioxidant capacity from the root of Salacia chinensis L. Journal of Food Quality, v.2017, p.1-8, 2017. Available from: <https://www.hindawi.com/ journals/jfq/2017/9305047/>. Accessed: mar. 19, 2017. doi: $10.1155 / 2017 / 9305047$.

OU, B. et al. Development and validation of an improved oxygen radical absorbance capacity assay using fluorescein as the fluorescent probe. Journal of Agricultural and Food Chemistry, v.49, n.10, p.4619-4626, 2001. Available from: <http://pubs.acs. org/doi/pdf/10.1021/jf010586o $>$. Accessed: out. 28, 2013. doi: 10.1021/jf010586o.

PATIL, D.M.; AKAMANCHI, K.G. Ultrasound-assisted rapid extraction and kinetic modelling of influential factors: Extraction of camptothecin from Nothapodytes nimmoniana plant. Ultrasonics Sonochemistry, v.37, p.582-591, 2017. Available from: <https://doi.org/10.1016/j. ultsonch.2017.02.015>. Accessed: mar.15, 2017.

PANIWNYK, L. et al. The enhancement and scale up of the extraction of anti-oxidants from Rosmarinus officinalis using ultrasound. Ultrasonics Sonochemistry, v.16, n.2, p.287-292, 2009. Available from: <http://www.sciencedirect.com/science/ article/pii/S1350417708001120?via\%3Dihub>. Accessed: jun. 13, 2013. doi: 10.1016/j.ultsonch.2008.06.007.

ROCKENBACH I.I. et al. Ácidos fenólicos e atividade antioxidante em fruto de Physalis Peruviana L. Alimentos e Nutrição, v.19, n.3, p.271-276, 2008. Available from: <http://serv-bib.fcfar.unesp.br/seer/ index.php/alimentos/article/view/630/528>. Accessed: dez. 12, 2013.

SEPTEMBRE-MALATERRE, A. et al. Evaluation of nutritional and antioxidant properties of the tropical fruits banana, litchi, mango, papaya, passion fruit and pineapple cultivated in Réunion French Island, Food Chemistry, v.212, p.225-233, 2016. Available from: $<$ https://doi. org/10.1016/j.foodchem.2016.05.147>. Accessed: jan. 10, 2017.

SHIRSATH, S.R. et al. Intensification of extraction of natural products using ultrasonic irradiations-A review of current status. Chemical Engineering and Processing, v.53, p.10-23, 2012. Available from: <http://www.sciencedirect.com/science/article/pii/ S0255270112000219>. Accessed: mai. 03, 2015. doi: 10.1016/j. cep.2012.01.003.

WANG, J. et al. Recommendation for modifying current cytotoxicity testing standards for biodegradable magnesiumbased materials. Acta Biomaterialia, v.21, p.237-249, 2015. Available from: <http:/www.sciencedirect.com/science/article/ pii/S1742706115001828?via\%3Dihub>. Accessed: nov. 29, 2015. doi: 10.1016/j.actbio.2015.04.011. 